\title{
Development and Validation of Stability Indicating LC-PDA Method for Mycophenolate Mofetil in Presence of Mycophenolic Acid and Its Application for Degradation Kinetics and pH Profile Study
}

\author{
Vishnu P. Choudhari ${ }^{1}$ and Anna Pratima G. Nikalje ${ }^{2}$ \\ ${ }^{1}$ Maharashtra Institute of Pharmacy, MIT Campus, Paud Road, Kothrud, Pune, Maharashtra 411038, India \\ ${ }^{2}$ Postgraduate Department of Pharmaceutical Chemistry, Y.B. Chavan College of Pharmacy, Dr. Rafiq Zakaria Campus, Rauza Bagh, \\ Aurangabad, Maharashtra 431001, India \\ Correspondence should be addressed to Vishnu P. Choudhari; viraj1404@rediffmail.com
}

Received 30 April 2014; Revised 5 June 2014; Accepted 5 June 2014; Published 30 June 2014

Academic Editor: Irene Panderi

Copyright (C) 2014 V. P. Choudhari and A. P. G. Nikalje. This is an open access article distributed under the Creative Commons Attribution License, which permits unrestricted use, distribution, and reproduction in any medium, provided the original work is properly cited.

\begin{abstract}
Factorial design tool applied for development of isocratic reversed-phase stability-indicating HPLC method for the analysis of mycophenolate mofetil (MMF) and its degradation products. MMF stress degradation products mycophenolate acid (MPA) and DP3 (USP impurity H) were isolated and used for quantitation. Separation achieved on a Symmetry C18 $(250 \mathrm{~mm} \times 4.6 \mathrm{~mm}, 5.0 \mu)$ column using a methanol: acetate buffer $(75: 25 \mathrm{v} / \mathrm{v}), \mathrm{pH} 6.0$ (adjusted with acetic acid), at $0.5 \mathrm{~mL}$ flow rate, column maintained at $55^{\circ} \mathrm{C}$, and data integrated at $251 \mathrm{~nm}$. MMF is subjected to hydrolysis, oxidation, heat degradation, and so forth; under all these conditions degraded products are well separated. The method validation characteristics included accuracy, precision, linearity, range, specificity, and sensitivity. Robustness testing is conducted to evaluate the effect of minor changes to the chromatographic conditions and to establish appropriate system suitability parameters. The proposed method is used to investigate kinetics of acid, alkali hydrolysis and oxidation process. Major degradation products MPA and DP3 were isolated and quantitated. Characterization of MPA by NMR and LC-MS/MS and other degraded products by LC-MS/MS is attempted successfully. The method is used successfully for the quality assessment of three MMF drug commercial formations and its acid, alkali, and oxidative degradation kinetics study.
\end{abstract}

\section{Introduction}

Mycophenolate mofetil (MMF) is chemically 2-(morpholin4-yl) ethyl (4E)-6-(4-hydroxy-6-methoxy-7-methyl-3-oxo1,3-dihydroisobenzofuran-5-yl)-4-methylhex-4-enoate. It is inhibitor of nucleic acid synthesis. It is the ester moiety of mycophenolic acid (MPA). It is a white or almost white crystalline powder and is used as immunosuppressive [1]. HPLC and HPTLC analytical methods for dissolution study of MMF in capsules, for its assay in bulk and dosage forms, [2-6] are reported. Bioanalytical and immunoassay methods are available for its determination individually or in presence of MPA [7-9] and one UV dissolution method is reported [10].
Its degradation products in aqueous solution are studied [11]. Stability-indicating HPLC and LC-MS/MS methods [12, 13] are reported where structural elucidation of degraded product and separation of the stress degraded product is lacking. MMF is included in BP, EP, and USP and assayed by potentiometry $[14,15]$. Isocratic LC method was described in proposed USP monograph $[16,17]$ for MMF tablet and capsule assay using mobile phase acetonitrile: water containing $0.3 \%$ triethylamine $(30: 20 \mathrm{v} / \mathrm{v}), \mathrm{pH} 5.3$ (adjusted with phosphoric acid) with run time of $10 \mathrm{~min}$. Proposed isocratic RPHPLC-PDA method has many advantages, which includes mass spectrometry compatible and simple methanol and acetate buffer mixture used as mobile phase and the method 
<smiles>COc1c(C)c2c(c(O)c1C/C=C(\C)CCC(=O)OCCN1CCOCC1)C(=O)OC2</smiles>

Mycophenolate mofetil (MMF)<smiles>COc1c(C)c2c(c(O)c1C/C=C(\C)CCC(=O)O)C(=O)OC2</smiles>

Mycophenolic acid (MPA)<smiles>COc1c(C)c2c(c(O)c1C/C=C(\C)CCC(=O)OCCN1CCOCC1)C(=O)OC2</smiles>

Mycophenolate mofetil N-oxide (USP impurity G)<smiles>COc1c(C)c2c(c(O)c1CC[C@]1(C)CCC(=O)O1)C(=O)OC2</smiles>

USP impurity H (DP3)<smiles>COc1c(C)c2c(c(O)c1C/C=C(C)/C=C/C=O)C(=O)OC2</smiles>

$\mathrm{DP}_{2}$

FIgURE 1: Structure of MMF and its major degraded products.

is stability indicating and highly sensitive. Quantitation of MMF, MPA, and DP3 (USP reported impurity $\mathrm{H}$ ) is achieved (Figure 1); proposed method is capable of separating all the stress degraded products with short run time. Accordingly, the aim of the present study was to establish inherent stability of MMF through stress studies under a variety of ICH recommended test conditions [18] and to develop a sensitive stability-indicating assay method with MS compatible and simple mobile phase and structural elucidation of the stress degraded products.

\section{Experimental}

2.1. Reagent and Chemicals. HPLC grade methanol was purchased from Merck (Mumbai, India). Analytical grade acetic acid and ammonium acetate were purchased from Loba Chemie Pvt. Ltd., Mumbai. Tablet used for analysis was Mycophen 250 (manufactured by Micro Labs Ltd., Hosur, India, batch number MYLH0001) and capsules used were Cellcept (imported and disturbed by Taksal Pharma Pvt. Ltd., New Delhi, batch number m1201) and Mycept (manufactured by Panacea Biotech Ltd., Solan, batch number 4669502), each containing $250 \mathrm{mg}$ of MMF. Pure drug sample of MMF (\% purity 99.6) and standard MPA (\% purity 99.8) were kindly supplied as a gift sample by Panacea Biotech Ltd., Solan, and standard hydrochlorothiazide (HTZ) (\% purity 99.78) was gift by Cipla Ltd., Mumbai.

2.2. Chromatographic Conditions and Software. The HPLC system is equipped with binary pump (model Waters 515 HPLC pump), autosampler (model 717 plus), column oven (model-Waters CHM), and PDA detector (Waters 2998). Data collection and analysis were performed using Empowerversion 2 software. Separation was achieved on Symmetry $\mathrm{C} 18(250 \mathrm{~mm} \times 4.6 \mathrm{~mm}, 5.0 \mu)$ columns maintained at $55^{\circ} \mathrm{C}$. The column was supported with Waters symmetry C18 $(3.9 \times$ $20 \mathrm{~mm}, 5.0 \mu)$ guard column. Mobile phase composed of methanol : acetate buffer $(25 \mathrm{mM})(75: 25 \% \mathrm{v} / \mathrm{v}), \mathrm{pH}$ adjusted to 6.0 with acetic acid. The flow rate was $0.5 \mathrm{~mL} / \mathrm{min}$ and the
PDA detector was set at $251 \mathrm{~nm}$; the injection volume was $20 \mu \mathrm{L}$. Trial version of Minitab 15.1.2 software was used for optimization study.

2.3. Preparation of Standard and Sample Solutions and Calibration Curve. A stock solution of MMF, MPA, and DP3 (USP impurity H) containing $1000 \mu \mathrm{g} / \mathrm{mL}$ was prepared, separately, in methanol. From these stock solutions working solutions of MMF 0.1-120, MPA 0.08-16, and DP3 $0.06-12 \mu \mathrm{g} / \mathrm{mL}$ were prepared in mobile phase. For preparation of calibration curve mixed standard solutions of MMF, MPA, and DP3 from stock solutions were prepared and injected onto the column and calibration curve was prepared by using concentration and area of chromatographic peaks. System suitability test (SST) standard mixture containing MMF, MPA, and DP3, 60, 8, and $6 \mu \mathrm{g} / \mathrm{mL}$, respectively, was prepared by mixing and diluting stock solutions with mobile phase. For preparation of sample, solution powder from twenty tablets/capsules equivalent to $100 \mathrm{mg}$ of MMF was transferred to a flask containing $80 \mathrm{~mL}$ of methanol, sonicated for $5 \mathrm{~min}$, and filtered. Filter was rinsed with methanol; filtrate was transferred to flask and volume was made to $100 \mathrm{~mL}$ with methanol; it was diluted suitably with mobile phase to contain $60 \mu \mathrm{g} / \mathrm{mL}$ of $\mathrm{MMF}$, filtered through $0.45 \mu \mathrm{m}$ Nylon 66-membrane filter, and used for analysis.

2.4. Method Validation. The HPLC method was validated in terms of precision, accuracy, specificity, sensitivity, robustness, and linearity according to ICH guidelines. Assay method precision (interday and intraday) was determined using nine-independent test solutions and precision of repeatability was performed by six-time injection of the solution. Assay method was evaluated with the recovery of the standards from excipients by spiking standards at three levels $(50 \%, 100 \%$, and $150 \%)$ to preanalyzed formulation. Values of limit of detection (LOD) and limit of quantification (LOQ) were calculated by using $\sigma$ (standard deviation of response) and $b$ (slope of the calibration curve) and by using equations, $\mathrm{LOD}=(3.3 \times \sigma) / b$ and $\mathrm{LOQ}=(10 \times \sigma) / b$. 
Calculated values of LOD and LOQ were confirmed by repeated injections of samples containing amounts of analyte in the range of LOD and LOQ. To determine the robustness of the method, the final experimental conditions were purposely altered and the results were examined. The flow rate was varied by $( \pm) 5 \%$. Column temperature was varied by $( \pm) 2^{\circ} \mathrm{C}$ and effect of column from different suppliers was studied. Measurement wavelength was varied by $( \pm) 1 \mathrm{~nm}$, injection volume was changed $( \pm) 2 \mu \mathrm{L}$, \% organic was changed by $( \pm) 5 \%$, and buffer strength was changed by $( \pm) 5 \mathrm{mM}$. Change in one parameter was considered for study at a time. Each parameter was studied by triplicate injection of the sample containing HTZ, MMF, MPA, and DP3. Robustness was evaluated by studying the effect of parameter change on assay values and resolution of the analytes injected and its effect on other system suitability parameters (retention time, number of theoretical plates, and peak symmetry). Long term $\left(4^{\circ} \mathrm{C}\right.$ for $5,10,15$, and 30 days) and autosampler stability $(6,12$, and $24 \mathrm{hrs}$ in autosampler) of the drug in solution were studied.

2.5. Procedure for Forced Degradation Study. Forced degradation of the drug product was carried out under thermolytic, photolytic, acid/base hydrolytic, and oxidative stress conditions. For photolytic stress, drug product in the solid state was irradiated with UV radiation with peak intensities at 254 and $366 \mathrm{~nm}$. The UV dose from the lamp of peak intensity at $366 \mathrm{~nm}$ was measured by use of a quinine monohydrochloride ( $2 \%$ solution in water) chemical actinometer as mentioned in the ICH guidelines [18]. Minimum desired exposure $\left(200 \mathrm{Wh} / \mathrm{m}^{2}\right)$ was observed after irradiation for $26 \mathrm{~h}$. Sample solution containing $1000 \mu \mathrm{g} / \mathrm{mL}$ MMF was subjected to selected stressed conditions, neutralized, appropriately diluted, and injected onto column. Samples except for photo oxidation were protected from light. For acid, base, and water induced degradation, solutions containing $1000 \mu \mathrm{g} / \mathrm{mL}$ of the drug were prepared in $0.1 \mathrm{~N} \mathrm{HCl}, 0.05 \mathrm{~N} \mathrm{NaOH}$, and water and analysed after 5, 6, and $12 \mathrm{hrs}$ exposure, respectively. For oxidative degradation, solution was prepared in water containing $10 \% \mathrm{v} / \mathrm{v}$ of $\mathrm{H}_{2} \mathrm{O}_{2}$ and analysed after $8 \mathrm{hrs}$. During dry heat study sample was exposed to $60^{\circ} \mathrm{C}$ for $8 \mathrm{hrs}$ in oven and analysed.

2.6. Degradation Kinetics. MMF solution containing 1000 $\mu \mathrm{g} / \mathrm{mL}$ was used for acid $(0.1 \mathrm{~N} \mathrm{HCl})$, alkali $(0.05 \mathrm{~N} \mathrm{NaOH})$, and oxidative $\left(10 \% \mathrm{H}_{2} \mathrm{O}_{2}\right)$ degradation; kinetics were studied at $60,70,80$, and $90^{\circ} \mathrm{C}$.

2.7. Preparation and Isolation of Alkali/Acid Induced Degraded Products, MPA and DP3. MMF, $1 \mathrm{~g}$, was dissolved in $50 \mathrm{~mL}$ methanol and refluxed with $100 \mathrm{~mL} 0.5 \mathrm{M} \mathrm{NaOH} / \mathrm{HCl}$ at $100^{\circ} \mathrm{C}$ for $15 \mathrm{~min}$. Subsequently, $\mathrm{pH}$ of the solution was adjusted to 2.5 with $5 \mathrm{M} \mathrm{HCl}$ to precipitate MPA. The precipitate was filtered, dried under vacuum, and used. Degraded product DP3 is observed during acid, alkali, oxidative degradation condition, which was isolated using TLC plates. DP3 was isolated from chloroform extract of degraded solution by using laboratory prepared silica gel G TLC plates.

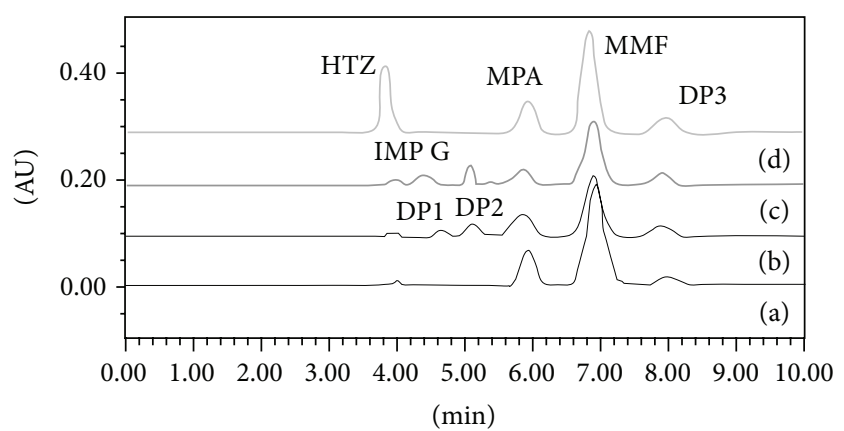

FIGURE 2: Chromatograms of stress degraded products of MMF with (a) $\mathrm{HCl}$, (b) $\mathrm{NaOH}$, (c) $\mathrm{H}_{2} \mathrm{O}_{2}$, and (d) system suitability chromatogram showing peaks of HTZ (internal standard) and analytes MPA, MMF, and DP3.

Mobile phase used for the TLC separation of DP3 was chloroform: toluene : methanol: acetic acid $(7: 3: 0.2: 0.1 \mathrm{v} / \mathrm{v})$ with development time of $20 \mathrm{~min}$, and it was eluted with $R_{f} 0.7$. Purity of isolated DP3 was confirmed by HPLC using PDA detector.

2.8. LC-MS/MS and NMR Study. The MS experiments were performed on LC-ESI-MS-MS/MS 410 prostar binary LC with 500 MS IT detector (Varian, USA) at IIT, Powai, Mumbai. LC unit consisted of prostar 210 binary pumps with prostar 410 autosampler. Previously described chromatographic conditions were used. MS was operated at enhanced scan mode, capillary voltage was 80 , and mass range was $50-600 \mathrm{~m} / \mathrm{z}$. Prom (version 3.01.01.00) software was used for data acquisition and processing. For ${ }^{1} \mathrm{HNMR}$ and ${ }^{13} \mathrm{CNMR}$, measurements of MMF and MPA were recorded on Mercury 300 NMR (Varian, USA) instrument at University of Pune, Pune, and $\mathrm{CDCl} 3$ was used as solvent.

\section{Results and Discussion}

3.1. Method Development. Factorial design was used as tool for optimization of the chromatographic conditions to develop a stability-indicating method. Various pilot trials were carried out to investigate different stationary phases, for example, C18 column (Symmetry and Kromasil), different mobile phases containing organic modifiers (methanol, acetonitrile, and THF), different buffers of different $\mathrm{pH}$ (3-6.5), and temperature $\left(30\right.$ to $\left.65^{\circ} \mathrm{C}\right)$. Our objectives were to achieve a peak tailing factor $<1.2$, retention times $\left(t_{R}\right)$ from 4 to $9 \mathrm{~min}$, and MMF and MPA resolution $>2$. From this experiment $\mathrm{pH}$ 6.0 was selected as most appropriate because at lower $\mathrm{pH}$ there is increase in baseline disturbances and peaks were not symmetric. Column was maintained at $55^{\circ} \mathrm{C}$ and methanol as organic modifier was selected to be the most appropriate. Effect of mobile phase flow rate and \% of methanol was studied by full factorial design (Table $1(\mathrm{a})$ ) and $2^{2}$ full factorial design experiments were carried out to study the effect on $t_{R}$ of MMF and MPA (Table 1(b)). By using full factorial design data linear equations obtained for MMF and MPA were $Y=$ $7.113-0.4343 x_{1}+1.0478 x_{2}-0.0528 x_{1} x_{2}$ and $=6.1515-$ $0.5265 x_{1}+0.9135 x_{2}-0.008 x_{1} x_{2}$, respectively. From the data 
<smiles>COC1=C(C)C2COC(=O)C2C(O)=C1C/C=C(\C)CCC(=O)OC/C=[N+]1\C=C[O+](CCOC(C)(C)C)C(C)=C1C/C=C(\C)CCC(=O)O</smiles>

(a)<smiles>CCCCCCCCCCC(C)(C)C</smiles>

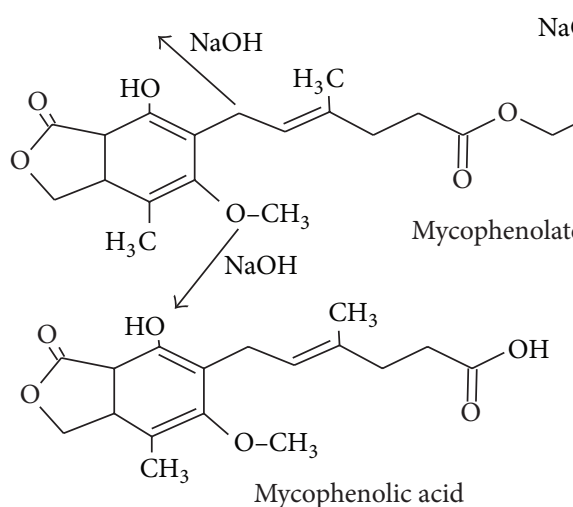<smiles></smiles><smiles>CCOC1=CC2COC(=O)C2C(O)=C1C1C=C[O+]=CC1</smiles><smiles>COC1=C(C)C2COC(=O)C2C(O)=C1C/C=C(\C)CCC(=O)O</smiles>

Impurity H (DP3)

(b)<smiles>COc1c(C)c2c(c(O)c1C/C=C(\C)CCC(=O)OCCN1CCO[C@H](C(=O)O)C1=O)C(=O)OC2</smiles>

(c)

FIgURE 3: Proposed mechanism of (a) acid, (b) alkali, and (c) oxidative stress degradation of MMF.

obtained (Table $1(\mathrm{c})$ ), it can be concluded that there is no interaction between the variables and flow rate does not play an important role. Methanol $\%$ affects $t_{R}$ and is considered as main effect. Target values of $t_{R}$ for MPA (6.0) and MMF (7.0) were fixed and weight $=1$ was assigned to it to obtain optimum conditions. HPLC runs were carried out by varying the \% of methanol in mobile phase and final chromatographic conditions selected were Symmetry C18 (250 mm $\times$ $4.6 \mathrm{~mm}, 5.0 \mu$ ) column maintained at $55^{\circ} \mathrm{C}$ using column oven. Mobile phase composed of methanol: acetate buffer $(\mathrm{pH} 6.0)(75: 25 \mathrm{v} / \mathrm{v})$. The flow rate was $0.5 \mathrm{~mL} / \mathrm{minutes}$, the PDA detector was set at $251 \mathrm{~nm}$, and injection volume was $20 \mu \mathrm{L}$.

3.2. Method Validation. The method was validated according to $\mathrm{ICH}$ guidelines. The following validation characteristics were addressed: linearity, range, accuracy, precision, specificity, sensitivity (LOQ and LOD), and robustness. Among drotaverine, HTZ, diclofenac sodium, etoricoxib, and atenolol, hydrochlorothiazide (HTZ) was observed as the most appropriate internal standard (IS) with values of peak symmetry, theoretical plates, and resolution well within limit. Assay value determined for three formulations was in the range of $100 \pm 1.33 \%$ with $\%$ RSD $<1.2$. Specificity of the method was determined by analyzing samples containing a mixture of the drug product excipients, samples containing MMF, MPA, and DP3, and stress degraded samples. All chromatograms were examined to determine if MMF, MPA, and DP3 coeluted with each other or with any excipient peak. Linear least square regression and LOD and LOQ data summarized in Table 2 indicate linearity and sensitivity of the method. Accuracy and precision were established for MMF, MPA, and DP3. Results for the accuracy of analytes tested in drug products by 
TABLE 1: Results of method optimization.

(a) Factors and their low (-), high (+), and zero (0) levels

\begin{tabular}{lccc}
\hline Factors & \multicolumn{2}{c}{ Factors level } & $(0)$ \\
\hline Methanol \% $\left(x_{1}\right)$ & $(-)$ & $(+)$ & 75 \\
Flow rate $(\mathrm{mL} / \mathrm{min})\left(x_{2}\right)$ & 70 & 80 & 0.65 \\
\hline
\end{tabular}

(b) Obtained results for $t_{R}$

\begin{tabular}{lcccc}
\hline & Factors & & & Retention factors \\
$x_{1}$ & $x_{2}$ & MMF & MPA \\
\hline- & - & 8.64 & 7.67 \\
- & + & 6.44 & 5.68 \\
+ & - & 7.69 & 6.46 \\
+ & + & 5.70 & 4.79 \\
\hline
\end{tabular}

(c) Effect of variables on $t_{R}$ of MMF and MPA

\begin{tabular}{lcc}
\hline Variable & & \% effect on $t_{R}$ of \\
& MMF & MMF \\
\hline$x_{1}$ (\% methanol) & 13.94 & 38.51 \\
$x_{2}$ (flow rate) & 85.84 & 61.04 \\
$x_{1} x_{2}$ (interaction) & 0.22 & 0.45 \\
\hline
\end{tabular}

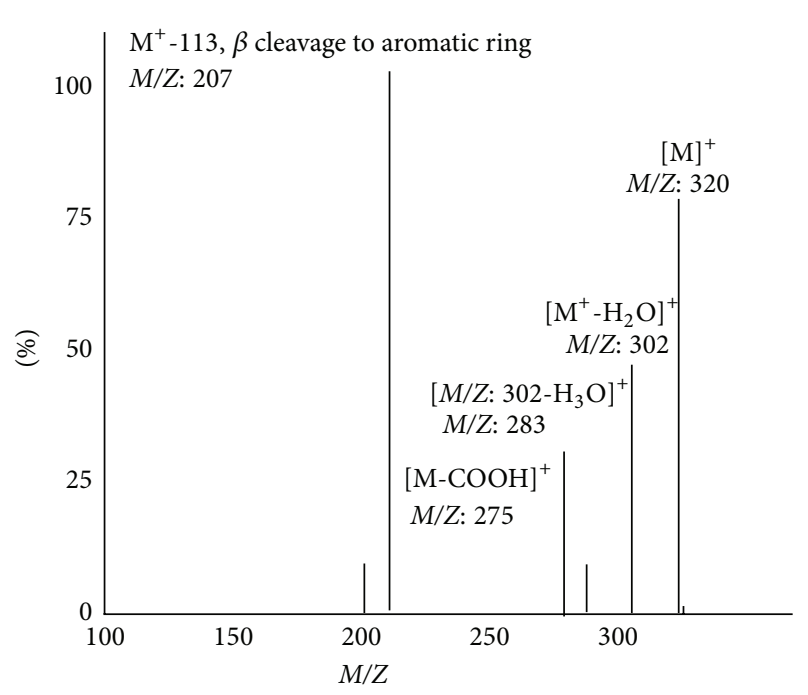

Figure 4: Mass fragmentation pattern of proposed impurity $\mathrm{H}$ (Enantiomer, DP3).

the technique of standard addition ranged from 98.87 to $101.6 \%$. Results of precision, SST, and recovery are summarized in Table 2. Robustness parameters studied were as described in the method validation section. During robustness study, resolution between MMF, MPA, and DP3 was $>2.2$ and assay variability of the method for MMF, MPA, and DP3 was always within $100 \pm 1.5 \%$. Values of other system suitability parameters were always within the limits indicating robustness of the method. The \%RSD of assay values of MMF and MPA during solution and autosampler stability experiments were within 1.6 and no significant changes were observed.
3.3. NMR Study. The PMR spectrum of MPA in deuterated chloroform showed protons signals $\delta_{\mathrm{H}}$ at $1.804 \mathrm{ppm}$ (singlet, $2 \mathrm{H}), 2.146 \mathrm{ppm}$ (singlet, 3H), 2.277-2.325 ppm (triplet, 1H) 2.378-2.460 (quartet, 2H), 3.373-3.395 (doublet, $2 \mathrm{H}$ ), 3.620 (singlet, $1 \mathrm{H}$ ), 3.757 (singlet, $3 \mathrm{H}$ ), 5.193 (singlet, $3 \mathrm{H}$ ), 5.228-5.270 (triplet, $2 \mathrm{H}$ ), and 7.840 (broad singlet $1 \mathrm{H}$ ). These signals were compared with ${ }^{1} \mathrm{HNMR}$ of standard sample and found at the same position, intensity, and multiplicity. ${ }^{13} \mathrm{C}$ NMR signals, for MMF and MPA, were observed at shift value and carbon numbers are $\delta_{\mathrm{C}} 11.23(\mathrm{C}-20), 15.86(\mathrm{C}-17)$, 22.42(C-18), 34.42(C-13), 60.79(C-12), 69.69(C-5), 106.17(C6), 116.41(C-15), 121.95(C-7), 122.67(C-9), 133.66(C-16), 143.84(C-4), 153.35(C-3), 163.33(C-8), 172.47(C-19), and 172.96(C-2); additional signals were observed for mofetil moiety of MMF at 53.69(C-23), 56.79(C-22), 61.48(C-24), and 66.59(C-25). The ${ }^{1} \mathrm{H}$ NMR and ${ }^{13} \mathrm{C}$ NMR data confirmed that the isolated compound is mycophenolic acid.

3.4. Stress Testing of MMF. Under the optimized conditions, MMF and its degradation products were well separated and are shown in Figures 2(a)-2(d). During the initial forced degradation experiments, it was observed that the MMF is very sensitive to alkaline stress condition and is extensively degraded by alkaline hydrolysis, and five degraded products (MPA, mycophenolate sodium, DP1, DP2, and DP3) were formed. During acid hydrolysis degraded products MPA and DP3 were formed. One of the oxidative stress degradation products of MMF, which is eluted at $t_{R} 4.5 \mathrm{~min}$ was found to be USP impurity G based on LC-MS data. Stress degraded products MPA and DP3 were isolated and used for study. Proposed chemical degradation schemes under acid, alkali, and $\mathrm{H}_{2} \mathrm{O}_{2}$ stress conditions are shown in Figures 3(a)-3(c), 


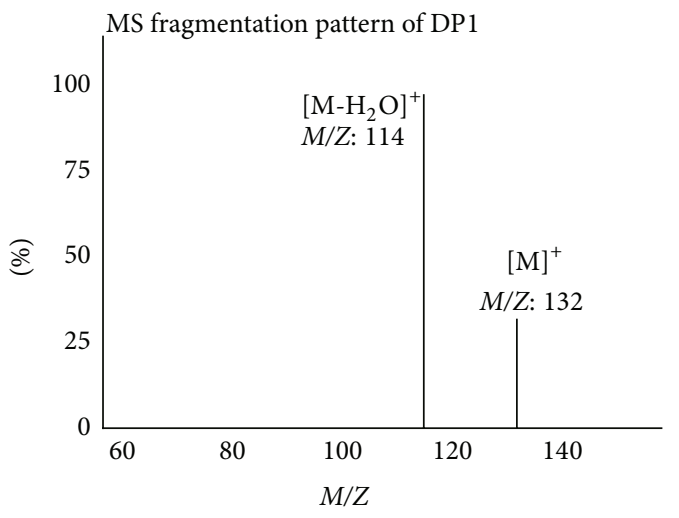

(a)

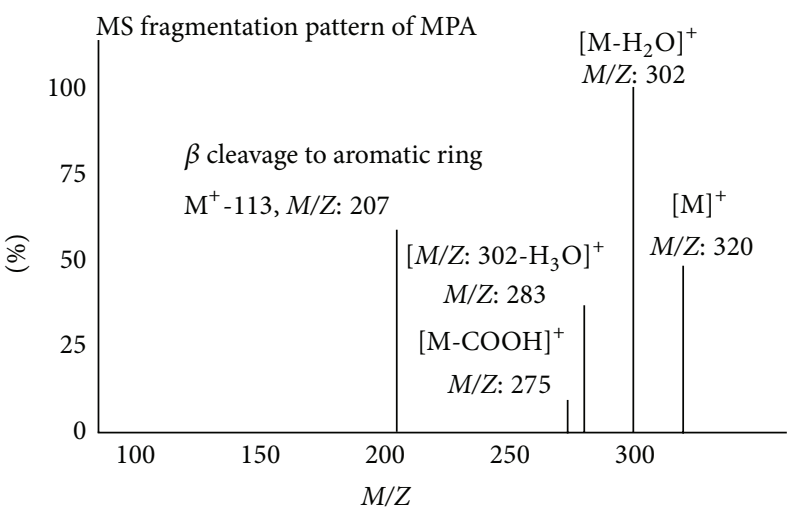

(b)

Figure 5: Mass fragmentation pattern of (a) DP1 and (b) mycophenolic acid.

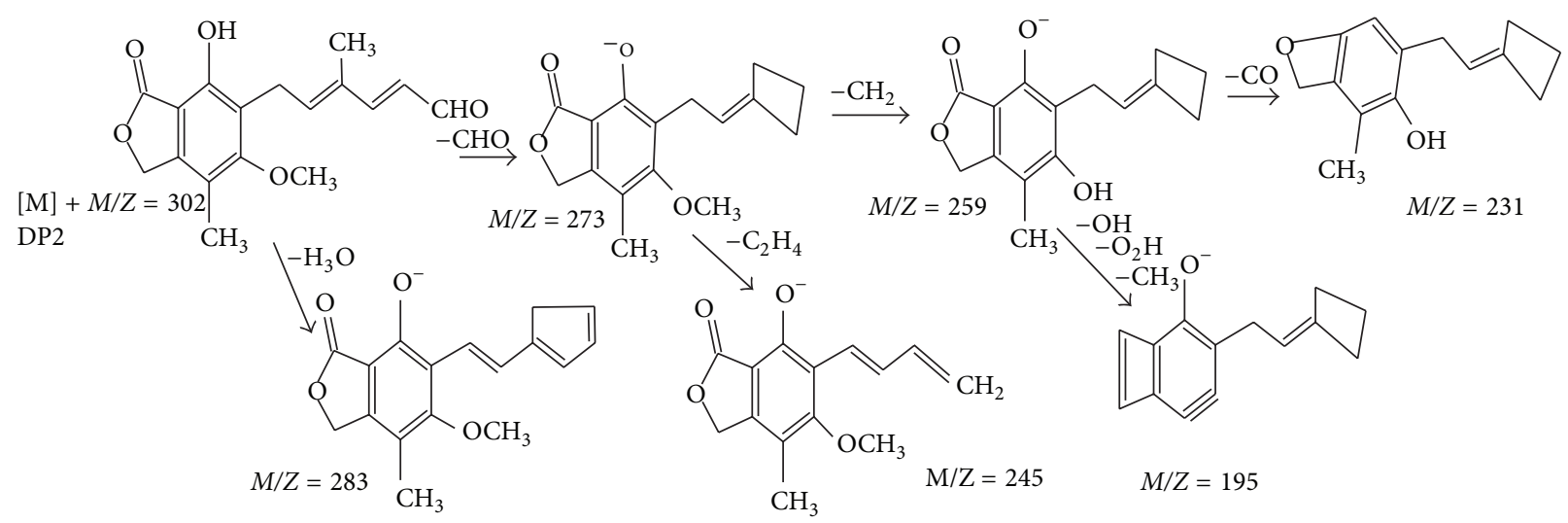

(a)

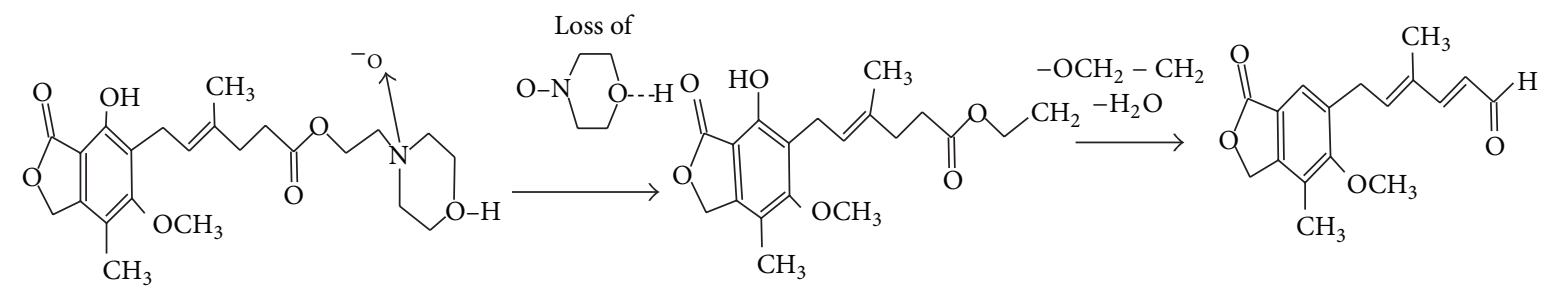

Impurity $\mathrm{G} \quad[\mathrm{M}]+M / Z=450$

$M / Z=347$

$M / Z=285$

(b)<smiles>COc1c(C)c2c(c(O)c1C/C=C(\C)CCC(=O)OCC[N+]1(CCO)CCOCC1)C(=O)OC[C@H]2O</smiles>

MMF protonated $[\mathrm{M}] \quad M / Z=435$

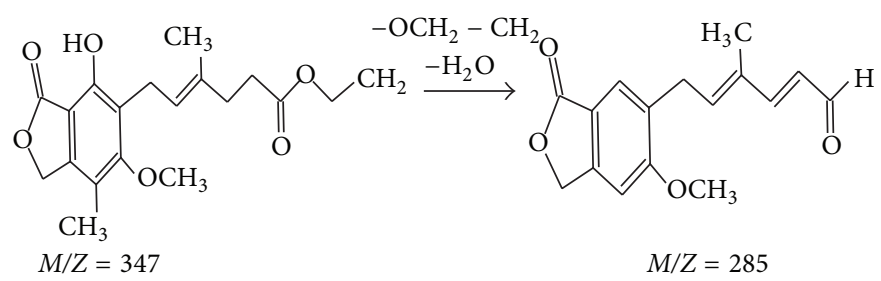

(c)

FIGURE 6: Mass fragmentation pattern of (a) proposed impurity DP2, (b) impurity G, and (c) mycophenolate mofetil. 


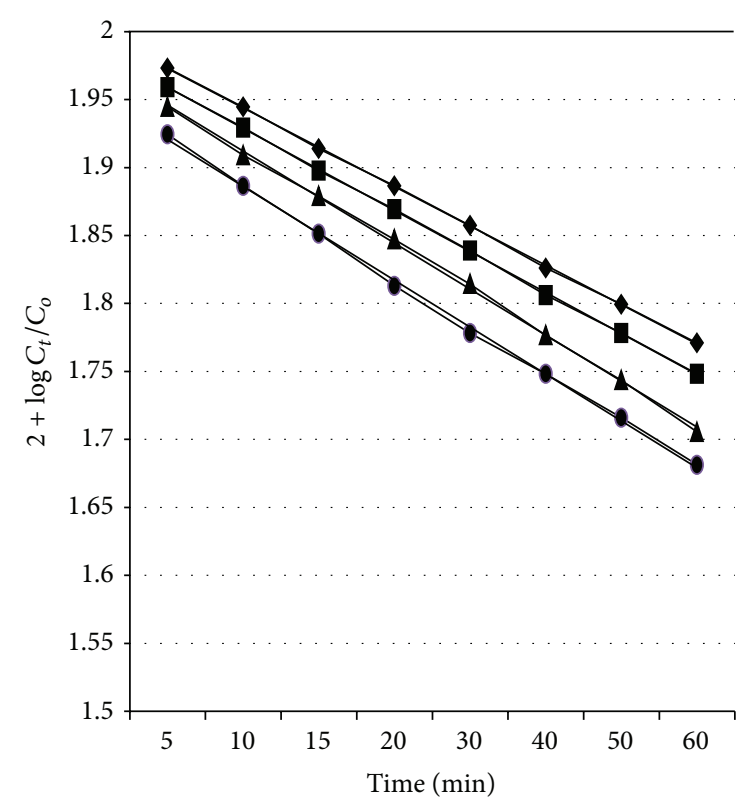

(a)

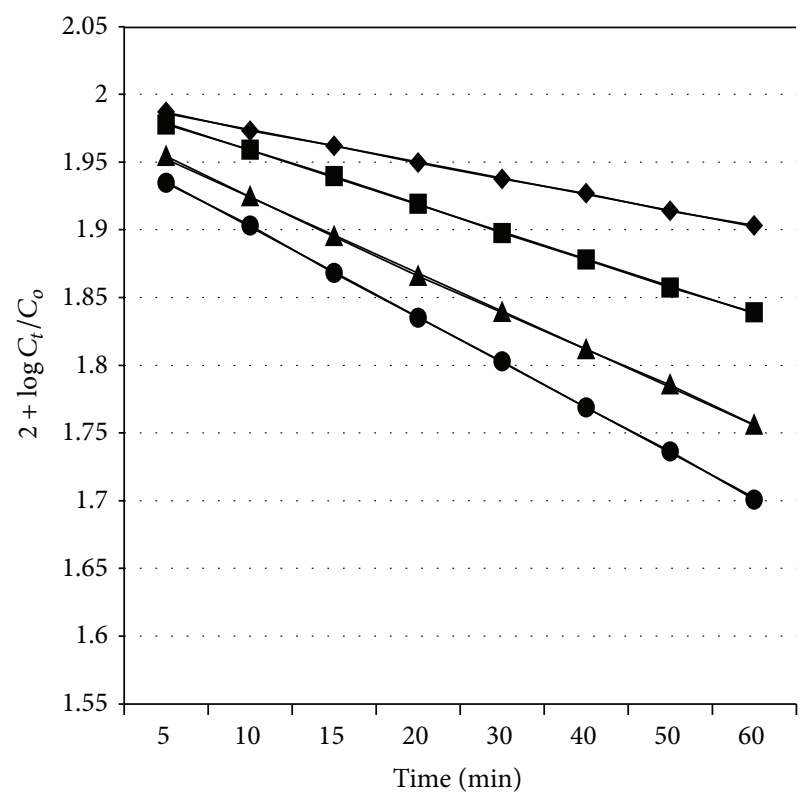

(c)

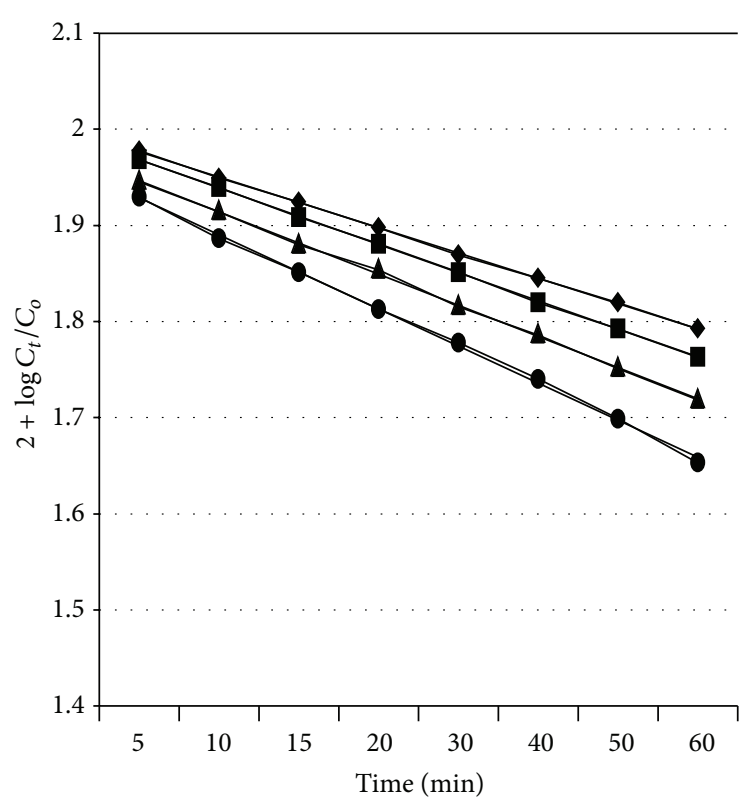

(b)

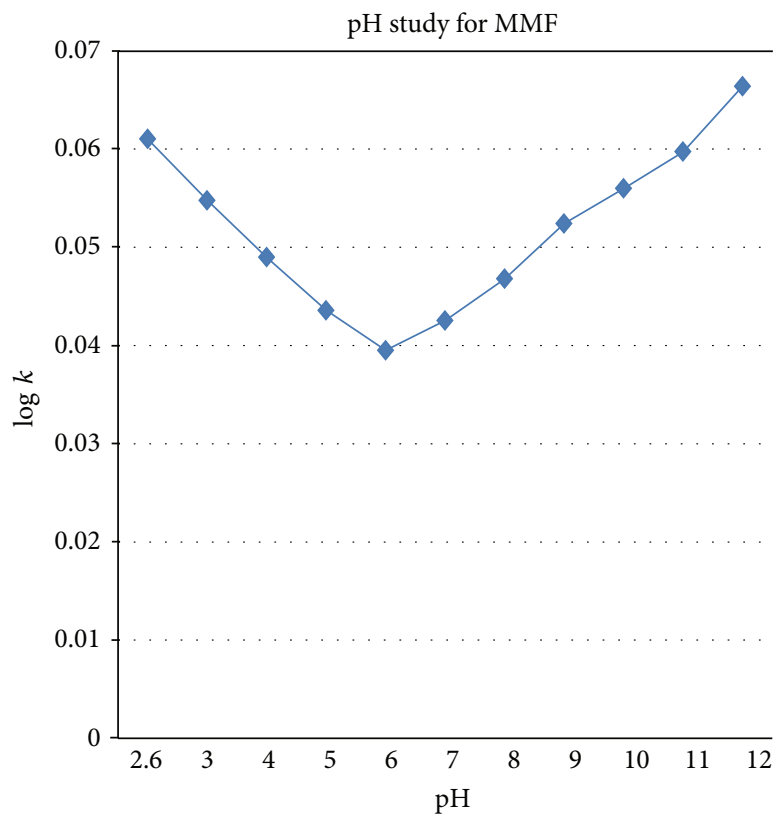

(d)

Figure 7: Degraded kinetics plot for MMF in (a) $0.1 \mathrm{~N} \mathrm{HCL}$, (b) $0.05 \mathrm{~N} \mathrm{NaOH}$, (c) $10 \% \mathrm{v} / \mathrm{v} \mathrm{H}_{2} \mathrm{O}_{2}$ at $60^{\circ} \mathrm{C}(\boldsymbol{}), 70^{\circ} \mathrm{C}(\boldsymbol{\bullet}), 80^{\circ} \mathrm{C}(\boldsymbol{\Delta})$, and $90^{\circ} \mathrm{C}$ $(\bullet)$, and (d) $\mathrm{pH}$ profile of MMF in Britton-Robinson buffer.

respectively. During various stress conditions, extent of degradation, peak purity, recovery of MMF, and mass balance (always >98.58) were calculated. Peak purity of stressed samples of MMF was checked by using PDA detector. The purity angle within the purity threshold limit obtained in all stress degraded samples demonstrated analyte peak homogeneity. Results of stress degradation, peak purity, and mass balance study are presented in Table 3. MPA, MMF degradation product, was isolated and identified by NMR and LC-MS/MS study and by comparing $t_{R}$ and UV spectrum of standard and degraded products. DP3 formed under all the stress conditions was isolated; its structure was determined by LC/MS study and found to be USP impurity $\mathrm{H}$ and is eluted at $t_{R}$ 7.9. It has MS fragmentation pattern like MPA except intensities of the MS peaks. It is less polar than MPA and was retained on $\mathrm{C} 18$ column for more time; its proposed structure by MS-MS study is shown in Figure 4. Mass fragmentation pattern and proposed structures of MPA and DP1 are shown in Figures 5(a) and 5(b). Mass fragmentation patterns of proposed impurity DP2, impurity G, and mycophenolate 
TABLE 2: Results of method sensitivity, linearity, precision, system suitability, and recovery of analytes.

\begin{tabular}{|c|c|c|c|}
\hline Parameter/analytes $\left(t_{R}\right)$ & MPA (5.9) & MMF (6.8) & DP3 (7.9) \\
\hline \multicolumn{4}{|l|}{ Method sensitivity } \\
\hline Limit of detection (LOD, $\mu \mathrm{g} / \mathrm{mL})$ & 0.026 & 0.121 & 0.02 \\
\hline Limit of detection (LOQ, $\mu \mathrm{g} / \mathrm{mL}$ ) & 0.078 & 0.366 & 0.06 \\
\hline Concentration range $(\mu \mathrm{g} / \mathrm{mL})$ & $0.08-16$ & $0.4-120$ & $0.06-12$ \\
\hline \multicolumn{4}{|c|}{ Regression equation $(Y=b \times$ Concentration $\pm a)$ data } \\
\hline Intercept $(a)$ & 1975.0 & -2289.8 & -2253.7 \\
\hline Slope $(b)$ & 70583.2 & 44428.2 & 86070.0 \\
\hline${ }^{\mathrm{a}} S_{a} \pm{ }^{*} t S_{a}$ (error in intercept) & $4786 \pm 9299.2$ & $6789.6 \pm 12628.6$ & $1731.9 \pm 3281.9$ \\
\hline${ }^{\mathrm{b}} S_{b} \pm{ }^{*} t S_{b}$ (error in slope ) & $734 \pm 1426.3$ & $118.3 \pm 286.4$ & $286.4 \pm 542.8$ \\
\hline Correlation coefficient $(r)$ & 0.999 & 0.999 & 0.999 \\
\hline \multicolumn{4}{|l|}{ Precision data, \% RSD } \\
\hline Repeatability, $n=6$ & 0.29 & 0.15 & 0.34 \\
\hline Intraday precision, $n=3 \times 3$ times & 0.4 & 0.35 & 0.43 \\
\hline Interday precision, $n=3 \times 5$ days & 0.45 & 0.42 & 0.52 \\
\hline \multicolumn{4}{|c|}{ System suitability data (USP-NF 29 section 621, pp. 2135) } \\
\hline Number of theoretical plates $( \pm S D)$ & $3450 \pm 32$ & $4255 \pm 26$ & $3865 \pm 50$ \\
\hline USP tailing factor $( \pm \mathrm{SD})$ & $1.01 \pm 0.01$ & $1.01 \pm 0.01$ & $1.00 \pm 0.042$ \\
\hline USP resolution & $5.9^{c}$ & 2.2 & 2.25 \\
\hline \multicolumn{4}{|c|}{ Recovery study at the level (\% recovery, \% RSD), $n=3$} \\
\hline $50 \%$ & $99.35,0.77$ & $101.6,0.59$ & $99.56,1.23$ \\
\hline $100 \%$ & $100.5,0.73$ & $100.3,0.45$ & $98.87,0.76$ \\
\hline $150 \%$ & $100.8,0.89$ & $99.98,0.34$ & $100.2,0.91$ \\
\hline
\end{tabular}

${ }^{*} t_{\mathrm{tab}}=1.86,1.895,1.943$ for MMF, DP1, and MPA, respectively $(P=0.05 ; \mathrm{df}=8),{ }^{\mathrm{a}}$ standard deviation (SD) of intercept, ${ }^{\mathrm{b}} \mathrm{SD}$ of slope, and ${ }^{\mathrm{c}}$ resolution with respect to IS HTZ peak.

TABLE 3: Result of stress degradation study, peak purity, and mass balance, $n=3$.

\begin{tabular}{|c|c|c|c|c|c|}
\hline \multirow{2}{*}{ Stress condition } & \multirow{2}{*}{ Degraded products reported at $t_{R}$} & \multirow{2}{*}{ MMF \% recovery } & \multicolumn{2}{|c|}{ Peak purity ${ }^{*}$} & \multirow{2}{*}{ Mass balance } \\
\hline & & & Peak angle & Peak threshold & \\
\hline $1 \mathrm{~mL}$ of $0.1 \mathrm{~N} \mathrm{HCl}, 5 \mathrm{~h}$ & 5.9 (MPA), 5.9 (DP3) & 89.45 & 0.247 & 0.415 & 99.96 \\
\hline $1 \mathrm{~mL}$ of $0.05 \mathrm{~N} \mathrm{NaOH}, 6 \mathrm{~h}$ & 4.61 (DP1), 5.9 (MPA), 5.9 (DP3) & 80.26 & 0.278 & 0.389 & 98.67 \\
\hline $2 \mathrm{~mL}$ of $30 \% \mathrm{H}_{2} \mathrm{O}_{2}, 8 \mathrm{~h}$ & 4.23 (IMP G), 4.61 (DP1), 5.9 (MPA), 7.9 (DP3) & 86.89 & 0.403 & 0.638 & 98.18 \\
\hline Short UV-254 nm, $26 \mathrm{~h}$ & 5.9 (MPA), 7.9 (DP3) & 93.43 & 0.189 & 0.278 & 99.57 \\
\hline Long UV-366 nm, $26 \mathrm{~h}$ & 5.9 (MPA), 7.9 (DP3) & 95.56 & 0.289 & 0.356 & 100.2 \\
\hline Wet heat, $12 \mathrm{~h}$ & 5.9 (MPA), 7.9 (DP3) & 96.45 & 0.137 & 0.267 & 99.78 \\
\hline Dry heat $-60^{\circ} \mathrm{C}, 8 \mathrm{~h}$ & 5.9 (MPA), 7.9 (DP3) & 92.87 & 0.265 & 0.315 & 99.98 \\
\hline
\end{tabular}

${ }^{*}$ Values of peak angle which are less than peak threshold indicate homogenous peak.

mofetil are shown in Figures 6(a)-6(c), respectively. The formation of MPA due to thermal degradation at various $\mathrm{pH}$ reported in literature [11] was confirmed. Peroxide catalyzed formation of MPA and N-oxide of MMF (USP impurity G) was supported by the experimental findings during proposed study.

3.5. Degradation Kinetics. Forced degradation of MMF by $\mathrm{HCl}, \mathrm{NaOH}$, and $\mathrm{H}_{2} \mathrm{O}_{2}$ resulted in decrease in peak area by time and it was found to be temperature dependent. Apparent first order degradation constant (Figure 7) and half-life at each temperature and Arrhenius equations were calculated. Apparent first order degradation constant $\left(2+\log C_{t} / C_{o} \pm\right.$ standard deviation) for $\mathrm{HCl}, \mathrm{NaOH}$, and $\mathrm{H}_{2} \mathrm{O}_{2}$ degradation at $60^{\circ} \mathrm{C}$ was found to be $1.799 \pm 0.08455,1.884 \pm 0.0645$, and $1.944 \pm 0.0292$, respectively. Half-life $\left(t_{1 / 2}\right.$, day $\left.{ }^{-1}\right)$ for $\mathrm{HCl}, \mathrm{NaOH}$, and $\mathrm{H}_{2} \mathrm{O}_{2}$ degradation at $60^{\circ} \mathrm{C}$ was found to be 0.7256, 0.7117, and 0.7084, respectively. Calculated Arrhenius equations at each of the selected conditions were $\log K=$ $1.223-\left(1.192 \times 10^{-3}\right) / T($ for $0.1 \mathrm{~N} \mathrm{HCl}), \log K=1.300-$ $\left(1.630143 \times 10^{-3}\right) / T$ (for $\left.0.05 \mathrm{~N} \mathrm{NaOH}\right)$, and $\log K=1.363-$ $\left(1.906 \times 10^{-3}\right) / T\left(\right.$ for $\left.10 \% \mathrm{H}_{2} \mathrm{O}_{2}\right)$.

\section{Conclusion}

A simple and efficient stability-indicating reverse-phase HPLC method was developed and was found to be accurate, 
precise, and linear across the analytical range and is reported for the first time. The method is simple, fast, sensitive, and specific for the determination and quantification of MMF, MPA, and DP3 with 9 min run time. The method can be used to assess the quality of commercially available MMF drug products and to study the kinetics of the MMF and MPA under different conditions. Mobile phase used is MS compatible; therefore, method can be used for LC-MS study of MMF and MPA and other degraded products. Hydrochlorothiazide can be used successfully as IS. Stress degraded products MPA and DP3 were isolated and structurally determined by ${ }^{1} \mathrm{H},{ }^{13} \mathrm{C}$ NMR, and LC/MS study, and quantitation of the degraded products was archived.

\section{Conflict of Interests}

The authors declare that there is no conflict of interests regarding the publication of this paper.

\section{Acknowledgments}

Authors wish to thank SAIF, IIT, Powai, Mumbai, for providing facility for LC-MS/MS study. The authors are grateful to Mrs. Fatma Rafiq Zakaria, Chairman of the Maulana Azad Education Trust, Dr. Maqdoom Farooqui, Principal of the Maulana Azad Postgraduate and Research Centre, Dr. Rafiq Zakaria Campus, Aurangabad, and Principal and Management of MAEER's Maharashtra Institute of Pharmacy, Pune, for providing necessary facility.

\section{References}

[1] S. Budavari, The Merck Index, Merck \& Co., Whitehouse Station, NJ, USA, 14th edition, 2001.

[2] L. Yang and D. He, "HPLC determination of dissolution of mycophenolate mofetil capsules," Yaowu Fenxi Zazhi, vol. 28, no. 7, pp. 1177-1179, 2008.

[3] A. L. Rao, P. V. Srinivas, and J. V. L. N. S. Rao, "A new validated RP-HPLC method for the estimation of mycophenolate mofetil in pure and tablet dosage form," Journal of Pharmaceutical Research and Health Care, vol. 2, no. 3, pp. 266-269, 2010.

[4] P. Raja Abhilash, K. Vasanth Kumar, and V. Sateesh Kumar, "Development and validation of new RP-UPLC method for the quantitative analysis of mycophenolate in tablet dosage form," The British Journal of Pharmaceutical Research, vol. 3, no. 3, pp. 363-373, 2013.

[5] K. Rajendra Prasad and S. Kathirvel, "Development and validation of RP-HPLC method for estimation of mycophenolate mofetil in bulk and pharmaceutical dosage form," Research Journal of Pharmaceutical Dosage Form and Technology, vol. 5, no. 1, pp. 43-46, 2013.

[6] S. Kathirvel, P. K. Rajendra, and B. K. Madhu, "Development and validation of HPTLC method for the determination of mycophenolate mofetil in bulk and pharmaceutical formulation," Pharmaceutical Methods, vol. 3, no. 2, pp. 90-93, 2012.

[7] U. D. Renner, C. Thiede, M. Bornhäuser, G. Ehninger, and H.M. Thiede, "Determination of mycophenolic acid and mycophenolate mofetil by high-performance liquid chromatography using postcolumn derivatization," Analytical Chemistry, vol. 73, no. 1, pp. 41-46, 2001.
[8] I. Tsina, M. Kaloostian, R. Lee, T. Tarnowski, and B. Wong, "High-performance liquid chromatographic method for the determination of mycophenolate mofetil in human plasma," Journal of Chromatography B: Biomedical Applications, vol. 681, no. 2, pp. 347-353, 1996.

[9] J. L. Beal, C. E. Jones, P. J. Taylor, and S. E. Tett, "Evaluation of an immunoassay (EMIT) for mycophenolic acid in plasma from renal transplant recipients compared with a high-performance liquid chromatography assay," Therapeutic Drug Monitoring, vol. 20, no. 6, pp. 685-690, 1998.

[10] S. P. Verma, O. Alam, P. Mullick, and N. Siddiqui Validated, "Ultra Violet Spectroscopy method for the dissolution study of mycophenolate mofetil immediate release $500 \mathrm{mg}$ tablets," Nature Precedings, 2009.

[11] E. Hooijmaaijer, M. Brandl, J. Nelson, and D. Lustig, "Degradation products of mycophenolate mofetil in aqueous solution," Drug Development and Industrial Pharmacy, vol. 25, no. 3, pp. 361-365, 1999.

[12] A. Protić, L. Živanovíc, M. Zečević, and B. Jocić, “Development of liquid chromatographic method for simultaneous determination of mycophenolate mofetil and its degradation product mycophenolic acid in dosage form," Journal of Chromatographic Science, vol. 47, no. 2, pp. 149-155, 2009.

[13] T. V. B. Reddy, N. S. Reddy, R. Golkonda, V. V. Sure, and R. Chintala, "Development of stability indicating liquid chromatography-mass tandem spectrometric method for the estimation of mycophenolate mofetil in bulk and pharmaceutical formulations," Journal of Pharmacy Research, vol. 7, pp. 640646, 2013.

[14] British Pharmacopoeia, 6th edition, 2009.

[15] European Pharmacopoeia, European Directorate for the Quality of Medicines and Health Care, Council of Europe, Strasbourg, France, 6th edition, 2008.

[16] http://www.usp.org/pdf/EN/pendingStandards/mycophenolateMofetilCapsules.pdf.

[17] http://www.usp.org/pdf/EN/pendingStandards/mycophenolateMofetilTablets.pdf.

[18] ICH Q2 (R1), Validation of Analytical Procedures: Text and Methodology, International Conference on Harmonization, Geneva, Switzerland, 2005. 

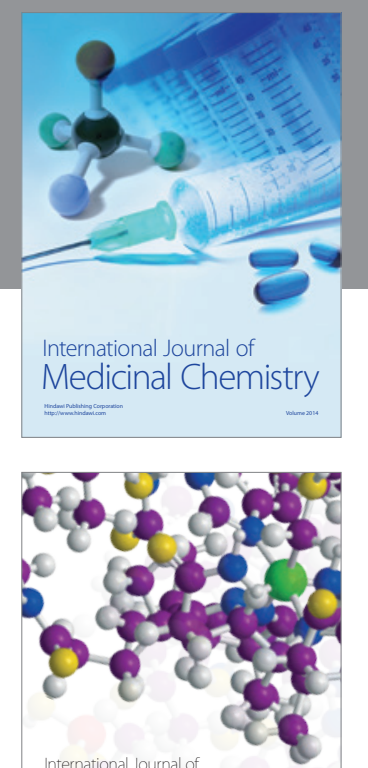

\section{Carbohydrate} Chemistry

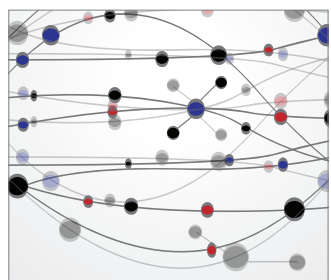

The Scientific World Journal
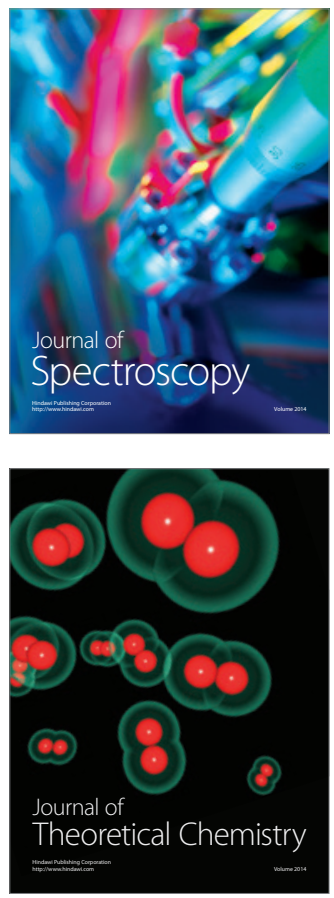
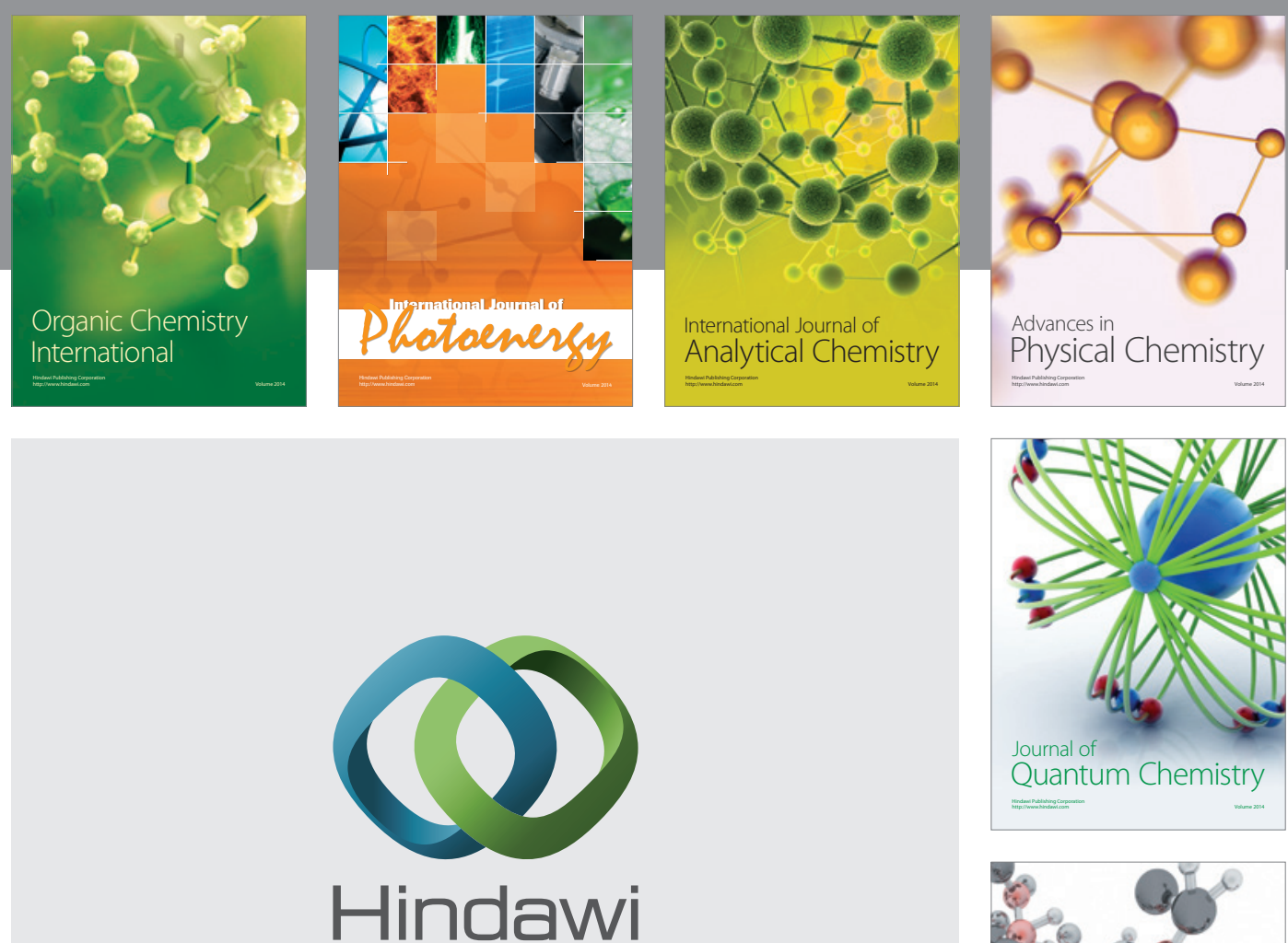

Submit your manuscripts at

http://www.hindawi.com

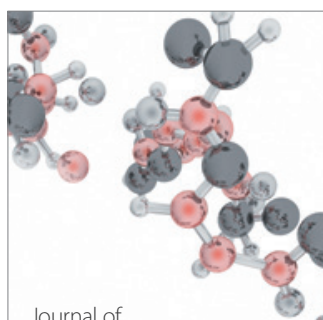

Analytical Methods

in Chemistry

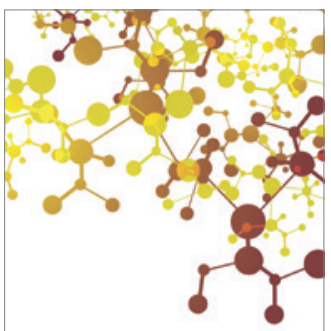

Journal of

Applied Chemistry

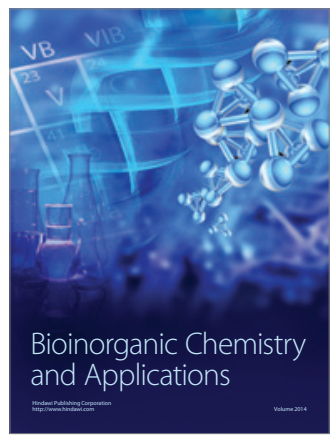

Inorganic Chemistry
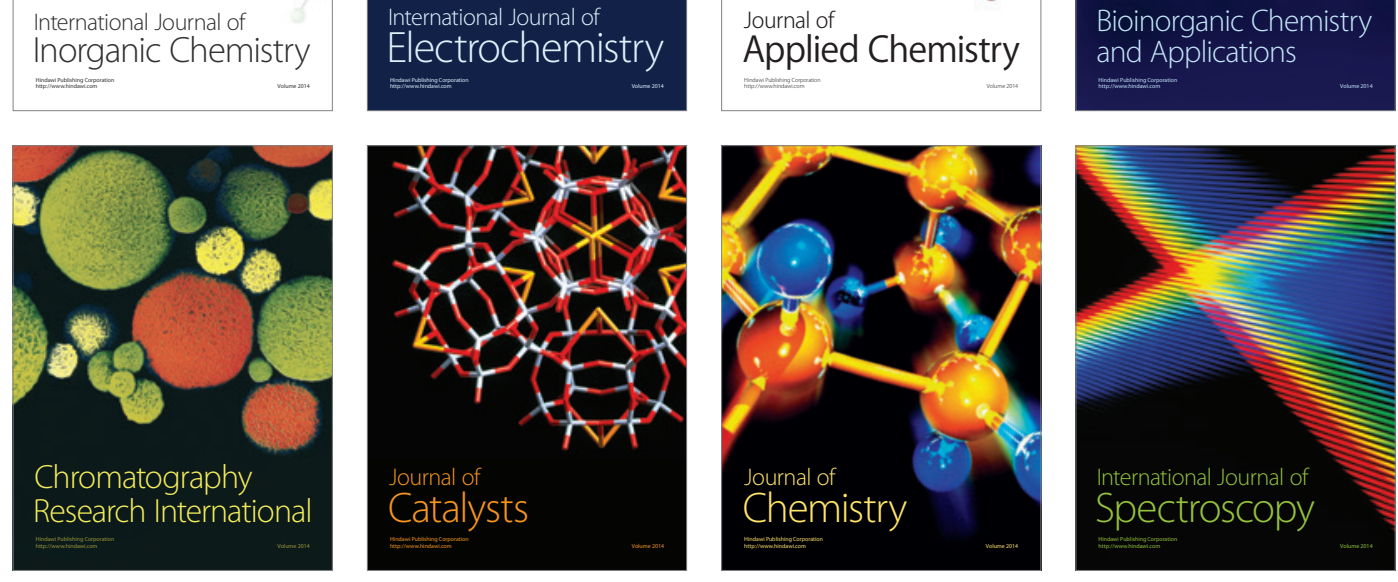